\title{
Testing of Decision Making Tools for Village Land Use Planning and Natural Resources Management in Kilimanjaro Region
}

\author{
Anthony Z. Sangeda ${ }^{*}$, Frederick C. Kahimba1, Reuben A. L. Kashaga1, Ernest Semu1, \\ Christopher P. Mahonge ${ }^{1}$, Francis X. Mkanda ${ }^{2}$ \\ ${ }^{1}$ Sokoine University of Agriculture, Morogoro, Tanzania \\ ${ }^{2}$ Sustainable Land Management Project, Regional Commissioner's Office, Moshi, Tanzania \\ Email: sangedaaz@gmail.com
}

Received 5 October 2014; revised 2 November 2014; accepted 18 November 2014

Copyright (C) 2014 by authors and Scientific Research Publishing Inc.

This work is licensed under the Creative Commons Attribution International License (CC BY). http://creativecommons.org/licenses/by/4.0/

cC) (i) Open Access

\section{Abstract}

This paper focuses on participatory testing of decision making tools (DMTs) at village level to assist in development of land use plans (LUPs) for sustainable land management (SLM) in Kilimanjaro Region, Tanzania. Data were collected using conditional surveys through key informant interviews with the project's district stakeholders in each district, focused group discussions with selected villagers and participatory mapping of natural resources. Soil health, land degradation, carbon stock, and hydrological conditions were assessed in the seven pilot villages in all seven districts using DMTs as part of testing and validation. Results indicated soils of poor to medium health, and land degradation as portrayed by gullies and wind erosion in lowlands and better in uplands. Carbon and forest disturbance status could not be assessed using one-year data but hydrological analysis revealed that water resources were relatively good in uplands and poor in the lowlands. Challenges with regard to land use include increased gully erosion, decreased stream flow, reduced vegetation cover due to shifting from coffee with tree sheds to annual crops farming, cultivation near water sources, and overgrazing. Empowering the community with decision making tools at village level is essential to ensure that village land uses are planned in a participatory manner for sustainable land and natural resources management in Kilimanjaro and other regions in Tanzania.

\section{Keywords}

Decision Making Tool, Land Use Planning, Sustainable Land Management, Natural Resources Management, Kilimanjaro

\footnotetext{
${ }^{*}$ Corresponding author.

How to cite this paper: Sangeda, A.Z., Kahimba, F.C., Kashaga, R.A.L., Semu, E., Mahonge, C.P. and Mkanda, F.X. (2014) Testing of Decision Making Tools for Village Land Use Planning and Natural Resources Management in Kilimanjaro Region. Open Journal of Soil Science, 4, 446-458. http://dx.doi.org/10.4236/ojss.2014.413044
} 


\section{Introduction}

Tanzania experiences deficiency in capacity, particularly on knowledge, information and decision making for land use planning at all levels [1]. The links between research and extension service are weak and research findings remain in shelves without being put into practice. These problems are compounded by the absence of a comprehensive monitoring system and decision making tools (DMTs) to guide village land use planning for natural resources management (NRM) at local level. Although some districts in Tanzania have been conducting isolated monitoring of environmental variables, there are no specific tools at village level to assess land degradation dynamics, carbon stock, soil health, or hydrological information, thereby limiting the application of adaptive management based on early detection of negative impacts. The lack of tools has limited the usefulness of planning and decision making to correct or mitigate the impact of current practices and to define land use policies at village level, where land degradation is experienced the most [2].

The government of Tanzania, with support from the global environment facility (GEF), through United Nations Development Programme (UNDP), is implementing a 4-year project aimed at reducing land degradation on the highlands of the Kilimanjaro Region. The project is in response to the fact that despite its local and global significance, the Kilimanjaro ecosystem is experiencing extensive degradation and deforestation driven by a set of complex interrelated factors, such as rapid population increase, land-use change, poor land-management practices, unsustainable harvesting of natural resources, declining commodity prices, and climate change [3]. Examples of degradation include completely deforested patches, removed vegetation cover and intense soil erosion in many areas that has resulted in big gullies. Such areas require some form of intervention to promote a favourable environment for the establishment of plants and to increase soil protection, thereby arresting further soil/land degradation. The project's goal is to ensure that "sustainable land management (SLM) provides the basis for economic development, food security, and sustainable livelihoods while restoring the ecological integrity of the Kilimanjaro Region's ecosystems”. Its purpose is to provide local land-users and managers with the enabling environment (policy, financial, institutional, capacity) necessary for the widespread adoption of sustainable land-management practices.

As part of capacity building, the project is facilitating integrated land-use planning at landscape and village levels because it is a necessary vehicle for institutionalization of SLM. Although land-use planning is mandated by the constitution, it is only being done to a very limited extent due to resource problems [2]. The project has, therefore, designed decision making tools that have been successfully tested with community groups in project pilot villages. This paper describes the testing of the decision making tools and preliminary findings of the tests that were conducted after the tools were designed. This paper presents findings of decision making tools for use at village and landscape levels that we designed and tested as part of the sustainable land management project in the Kilimanjaro Region.

\section{Materials and Methods}

\subsection{Description of Study Area}

The study was conducted in seven pilot project villages, each village drawn from one district within the Kilimanjaro Region. Three villages of Shighatini (Mwanga District), Ushiri (Rombo District), and Manio (Siha District) were from the uplands (1200 - 1900 m.a.s.l). Two villages of Roo (Hai District) and Sango (Moshi Rural District) were from midlands with moderate altitude (900 - 1200 m.a.s.l). The remaining two villages of Mnazi (Moshi Urban) and Mabilioni (Same District) were from the lowland areas (500 - 900 m.a.s.l). The location of the test sites allowed researchers to test the tools in all the heterogeneity within the Kilimanjaro Region. Due to differences in topo-sequence, these three categories of villages had different characteristics in terms of agroecology and socio-economic activities of the communities. For example, there were more conservation agriculture and less free grazing in the uplands compared to the lowlands.

The Kilimanjaro Region is located in the north-eastern part of Tanzania (Figure 1). It lies between latitudes $2^{\circ} 25^{\prime} \mathrm{S}$ and $4^{\circ} 15^{\prime} \mathrm{S}$, and between longitudes $36^{\circ} 25^{\prime} 30^{\prime \prime} \mathrm{E}$ and $38^{\circ} 10^{\prime} 45^{\prime \prime} \mathrm{E}$. The region is bordered by the country of Kenya on the north, Arusha Region on the north-west, Manyara Region on the west, and Tanga Region to the south-east [4]. Main relief features in the region include Mt. Kilimanjaro with a snow covered peak at (5895 m.a.s.l) and the Pare Mountain ranges running from north-west of Mwanga District to south-east of Same District. 


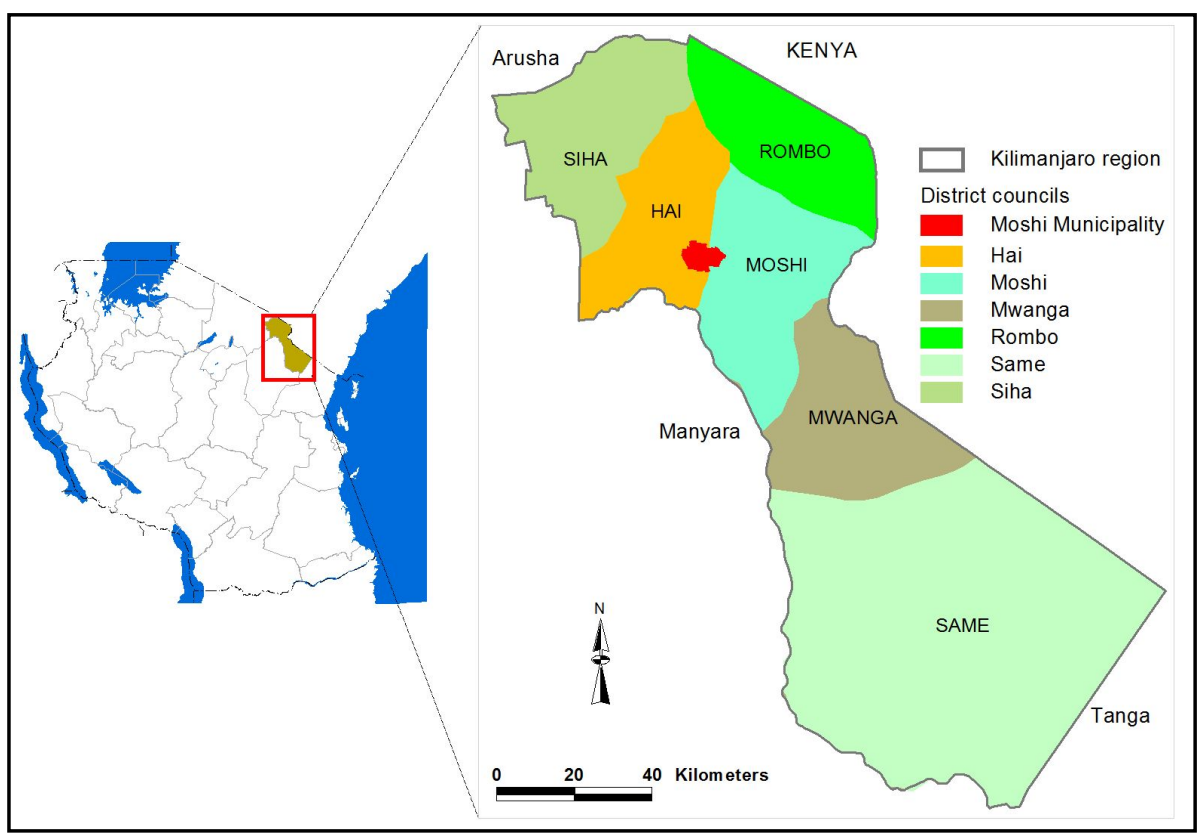

Figure 1. Location map showing sustainable land management (SLM) project area in Kilimanjaro Region, Tanzania.

The region has a population of 1,640,087 people, with an average annual growth rate of $1.8 \%$ [5]. About $48.7 \%$ of the total land area of $13,209 \mathrm{~km}^{2}$ or $1,320,900$ ha is arable, $21.3 \%$ is under game reserves, $15.3 \%$ under grasslands and rangelands, $12.4 \%$ under forest reserves, and $2.3 \%$ are water bodies (lakes, dams, and rivers). This amount of land gives an arable density of about 0.8 ha per capita, which is higher than the national figure of 0.21 per capita. Arable density is the number of people per unit area of arable land and is a measure of selfsustainability in terms of food production [6]. This result implies that self-sustainability in terms of food production in Kilimanjaro is lower than in the rest of Tanzania. The implication is that cultivation intensity in the region is higher than for the whole nation, which could be a factor contributing to land degradation.

The climate of the region is modified by the presence of the mountain ranges, with mean annual precipitation ranging from $400 \mathrm{~mm}$ in the lowlands to more than $1200 \mathrm{~mm}$ in the highlands, and more than $2000 \mathrm{~mm}$ in mountainous areas. The temperature of Kilimanjaro Region is variable depending on topo-sequence. Highlands are much cooler than lowlands with temperatures ranging between $15^{\circ} \mathrm{C}$ and $30^{\circ} \mathrm{C}$. Lowland maximum temperatures go as high as $40^{\circ} \mathrm{C}$ during the dry season. January to March are the warmest months. The region faces significant risks from climate change, with a rise in mean temperature, decrease in annual precipitation, and increase in variability with the rainfall patterns becoming increasingly more unimodal. These occurrences have increased the vulnerability as farmers may have less water available for crop production.

Kilimanjaro Region is also characterized with higher wind speeds. On the eastern part of the region in Same District, mid-day winds range between 15.2 - $24.5 \mathrm{~km} / \mathrm{hr}$ from September to March, and calms down to 13.3 $16.3 \mathrm{~km} / \mathrm{hr}$ from April to August. On the western part in lowlands of Hai District wind speeds are higher in the months of September to March (15.2 - $18.0 \mathrm{~km} / \mathrm{hr}$ ), and become lower from April to August (11.4 - $12.2 \mathrm{~km} / \mathrm{hr}$ ). The central part in Moshi town normally has mid-day wind speeds in ranges of 14.6 - $17.1 \mathrm{~km} / \mathrm{hr}$ from September to March, and 8.3 - $11.0 \mathrm{~km} / \mathrm{hr}$ from April to August [7]. This is an indication that the lowlands of Kilimanjaro Region are very vulnerable to wind erosion during the dry season, especially if the land is loosened e.g. by overgrazing and left bare without vegetation/crop cover as a result of harvesting all crop residues for animal feeds.

With regard to soils in Kilimanjaro Region they vary depending on the landscape. Generally the soils are volcanic in the uplands around Mount Kilimanjaro, and ferralistic soils in the Pare Mountains areas with alluvial plains in all the lowlands, mainly affected by salinity. Due to steep slopes in the region even the middle and lower altitude areas have suffered extensive soil erosion. Previous studies showed that soil erosion by water is a major problem in the region [8]. Although farmers in the area have traditionally practiced soil conservation as 
evidenced by the remnants of terraces, these practices are no longer institutionalized within the community groups, and hence they are being practiced by only a few farmers.

\subsection{Methods Used to Test Decision Making Tools}

To design tools that are suitable for the region, existing decision making tools (DMTs) for assessment of land degradation [9], estimation of carbon stocks [10] [11], soil health [12] [13], and hydrology [14] [15] were reviewed. These four tool kits were deemed adequate to enable framers make decisions about their land. The vigorous literature review was done by authors to familiarize various decision making tools used in other places of the world. However, many of the reviewed tools were those used at higher levels for decision makers. In contrast, the designed tools in this study aimed to be used at local level; hence a number of modifications and simplifications had to be made. Although some of the reviewed tools from the literature were in terms of graphical models, all the new designed tools were standardized into tabular frameworks, which are user friendly to semi-illiterate local communities.

The draft tools were designed in office after data collection, which was done prior to testing in the field using beneficiaries (the local community) in a participatory approach. During validation, the communities were involved to assess whether an indicator of the DMT was appropriate and relevant or not. All irrelevant indicators pointed in the first village were changed before testing the tool in the next village. In this case, researchers were meeting every evening to validate the tool based on the inputs and comments raised by villagers after which an updated version of the tool had to be printed for the next village and so on. All the tools used for testing and validation were translated into Kiswahili language which is the lingua franca in Tanzania.

A total of seventy (70) land users, ten (10) in each village were involved in testing the applicability of the tools. The villagers involved were selected based on their membership in a particular village committee. Representatives from land use, environment/natural resources, water and women committees, village extension officer, village executive officer, and village chairperson were involved in testing the tools.

The testing was conducted in a form of training where the researchers explained the importance of participatory land use planning and management of natural resources in the village. Communities were also told of the importance of using specific tools in data collection and monitoring with time. Additionally, they were introduced to various simplified equipment (like tape measure, infiltrometer, penentrometer etc.) for use, how they can be used to collect information, and how that information could help in land use and natural resources management within the village.

The work started in a classroom session for one hour where communities were introduced to all the four decision making tools and copies of each tool were distributed to them. The session was followed by a transect walk into the field. At each site, a nearby degraded land, forest, farm and water source was identified to be used as a medium for practical testing of the respective toolkits. While at each site (e.g. degraded area) the team was asked to open the land degradation tool kit and assess the extent of degradation using the indicators in the tool kit. In most cases researcher introduced the assessment methods in the first place and then communities in groups replicated the assessment thereafter. On each site and for each toolkit, the first test was done by the researcher as demonstration and the subsequent tests were then carried by communities in groups and later the results were compared.

\subsection{Topo-Sequence Effects on Land Use for Kilimanjaro Region}

The districts of Kilimanjaro are located in series along the Dar es Salaam-Arusha highway with the exception of Rombo District. Considering the longitudinal (east-west) cross section, the region was divided into two main parts; the eastern part covering the districts of Same, Mwanga and part of Moshi rural district, and the western part covering districts of Siha, Hai, Moshi urban, and western part of Moshi rural districts (Figure 1).

The climatic conditions of the eastern part districts were mainly modified by the presence of the Pare mountain ranges, characterized by low rainfalls especially in the lowlands $(<400 \mathrm{~mm})$ along the Pangani River areas. The central and western part climate was modified by the ecology of the Kilimanjaro Mountain, making it much cooler, covered with clouds most of the time, and experiencing higher rainfalls. Considering the topo-sequence, all the districts were divided into highlands, midlands, and lowland areas (Figure 2(a) and Figure 2(b)). The upland areas were characterized by permanent crop plantations, forest reserves, and steep slopes, some with soil conservation measures such as bench terraces (Figure 3), and higher population density in settlement areas. 


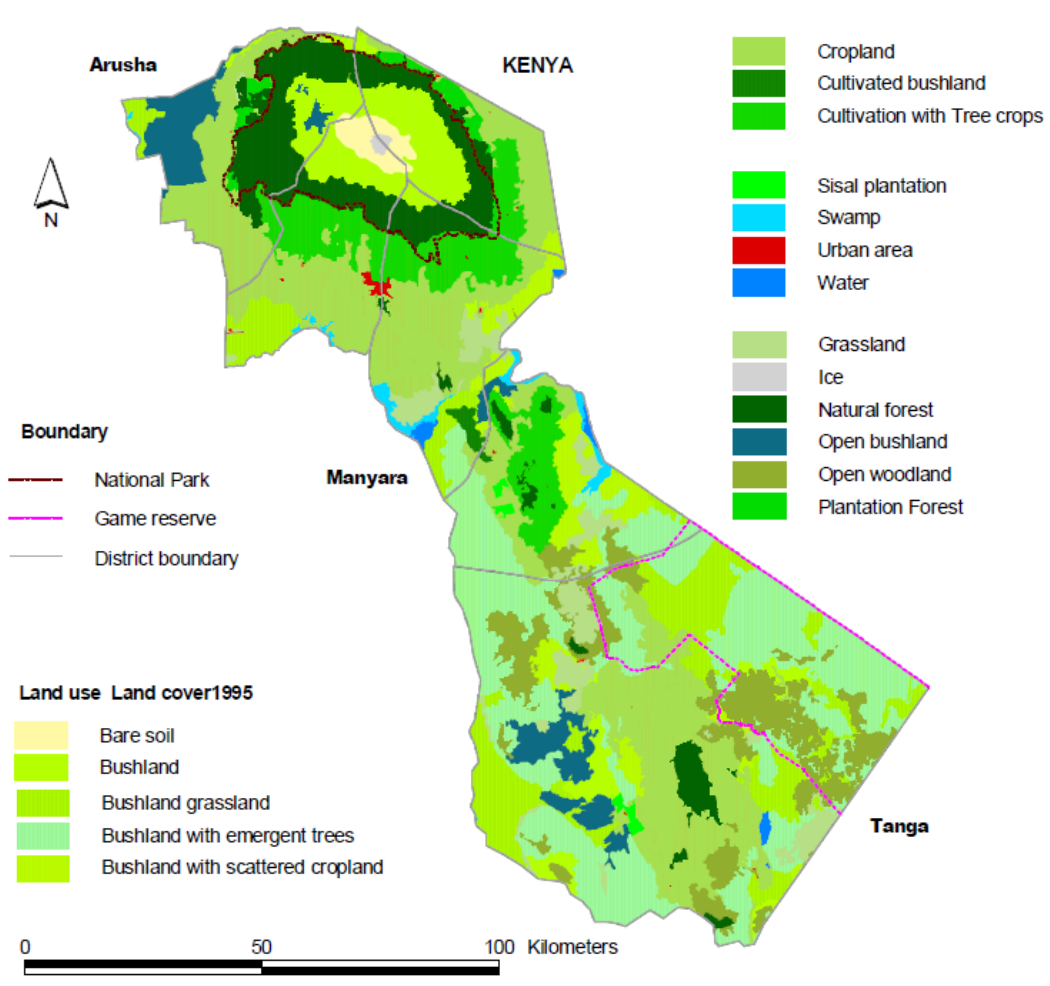

(a)

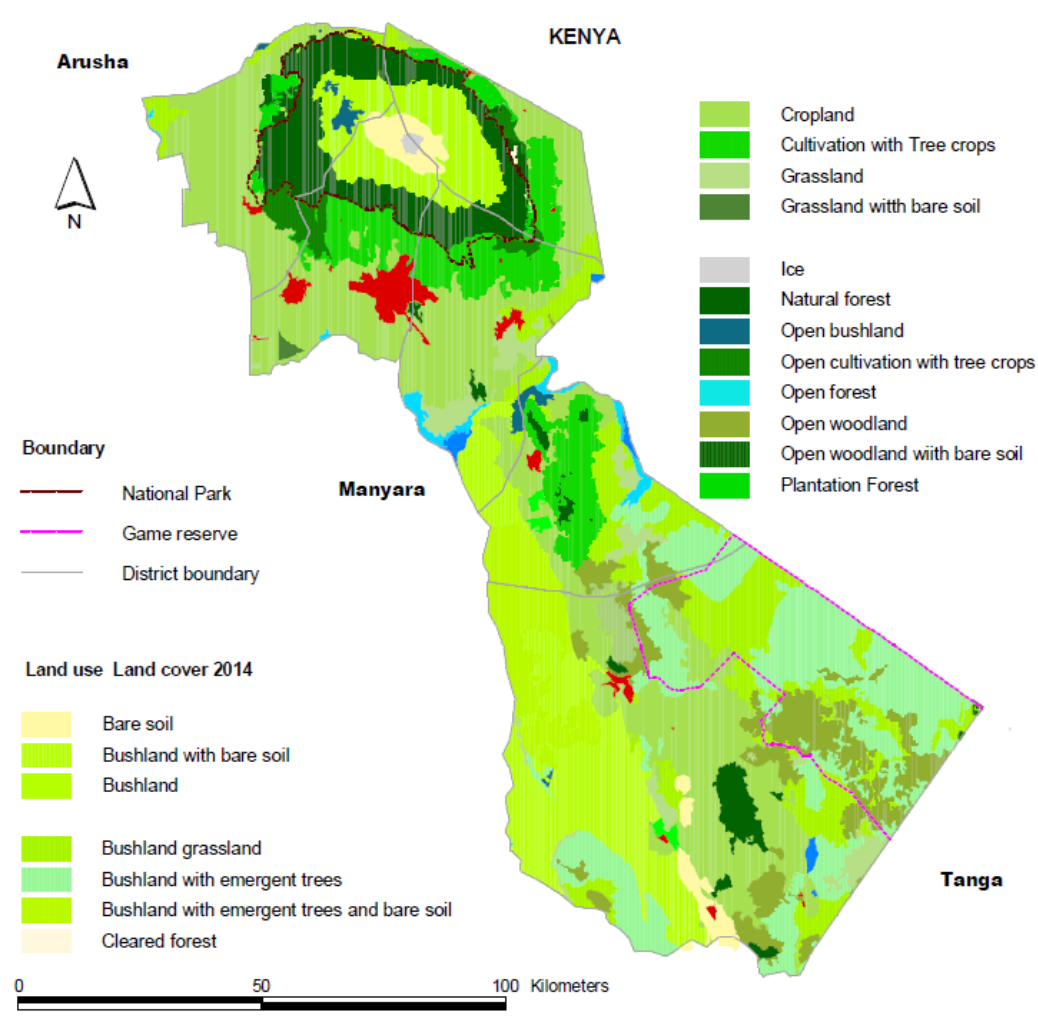

(b)

Figure 2. (a) Kilimanjaro Region land use map for 1995; (b) Kilimanjaro Region land use map for 2014. 


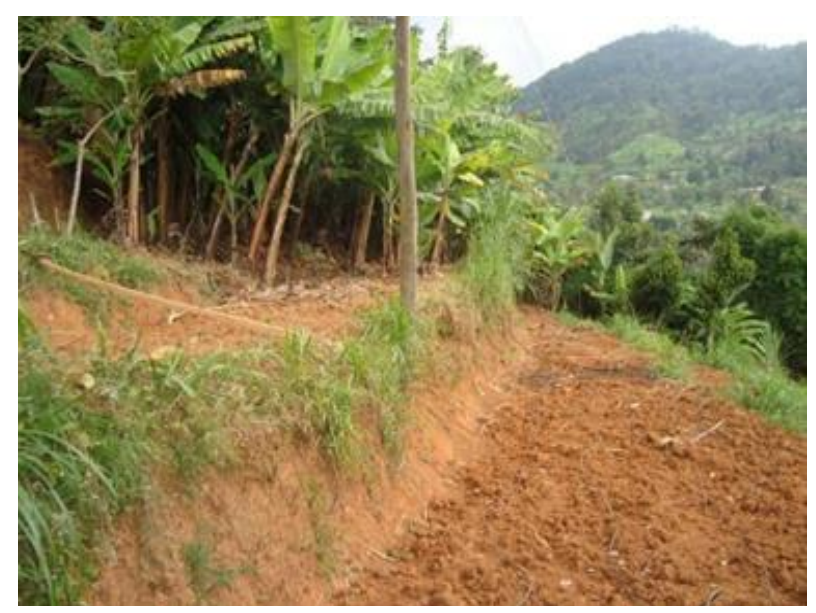

Figure 3. Terraces with elephant grass in the uplands of Kilimanjaro Region.

Gully erosion was not profound in this zone due to lesser accumulation of stream flows and existence of good forest cover as opposed to midlands and lowlands (Figure 4). However, the paradigm shift from perennial coffee plantations to maize farming has resulted in removal of tree sheds in the fields to create favorable environment for annual crops such as maize. This shift has caused most of the land in the uplands and midlands to remain bare during dry season as crop residues are harvested for animal feeds as it can be depicted in the temporal land use change maps (Figure 2(a) and Figure 2(b)).

The midland and lowland areas were characterized mainly by both permanent (mainly midlands) and seasonal crops. Lowland areas were also occupied by pastoral communities and seasonal cropping systems. Most of the fields in the lowlands were used as grazing fields making the soil loose and prone to both water and wind erosion.

\subsection{The Selection of Decision Making Tools}

The land degradation tool was designed to assess the extent and severity of land degradation in a village. It set indicators of land degradation and mitigation measures to prevent further degradation. Indicators for land degradation included soil erosion (sheet, rill and gully), loss of vegetation cover, time series of poor performance of crops in terms of growth and yield, and emergence of invasive plant species. Others included cultivation along steep slopes without conservation measures and development of settlements in the slopes of water catchment. Change of greenish colour of natural vegetation cover in water catchment areas was also identified as an indicator of land degradation. The community used the tool to monitor natural resources potential and existing land degradation conditions, and appreciated appropriate measures to take for different land degradation scenarios to ensure sustainable land management. The measures were categorized into short-term, medium-term and long-term based on the stage of land degradation (initial, intermediate and later stage).

The soil health assessment tool aimed at guiding the local community in mapping village soils based on soil health suitability. It assisted in allocating various village land uses based on soil fertility criteria and suitability. For example, fertile soils to be designated for agriculture while poor soils could be left for pasture and therefore demarcated for livestock and other village investments. The aim of soil health assessment was to inform the land users (communities) on characteristics of the soil, hence its ability to render relevant ecosystem functions commensurate with its environment and expectations. An example of assessment tool is given in Table 2.

The Carbon stock assessment tool was a simplified tool to assess changes in carbon stock. It used simple and readily available tools to measure amount of tree biomass/increment and assessing levels of forest disturbances. Measurements were easily done by local communities, but data analysis needed to be carried out by carbon experts using established allometric models. The assessment led to knowing the condition of the forest, which reflected the amount of carbon gained or lost. The information was regarded as important for planning i.e. if there were more loss in carbon then communities would be required to enforce rules and bylaws in managing forest resources, do enrichment planting or involve more village members in the management. 


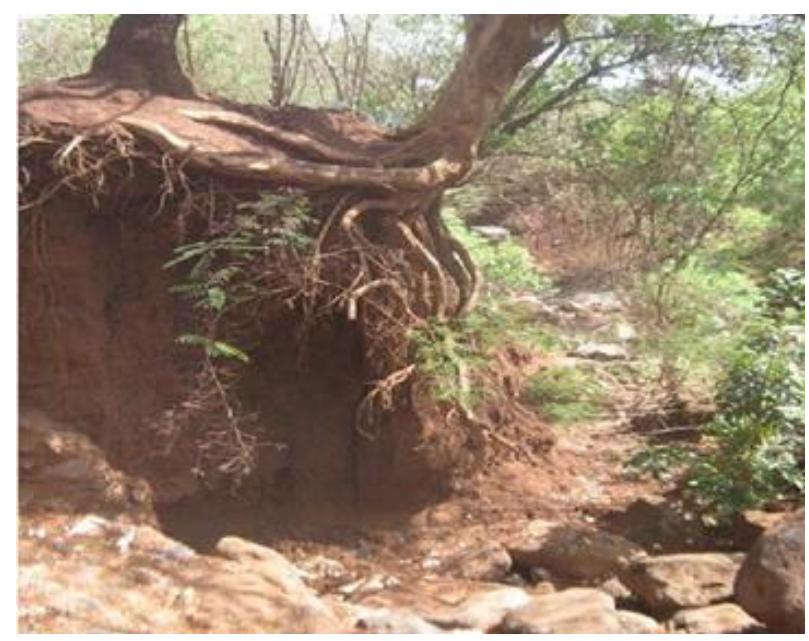

Figure 4. Land degradation in the lowlands of Kilimanjaro Region.

The hydrological/water resources assessment tool involved a participatory water sources and water points' mapping as a decision management tool for village land use planning. During the hydrological mapping various water sources such as rivers, springs, traditional canals, micro-dams (ndiva/nduwa) were mapped and their hydrological characteristics documented. Mapping water points involved locating water points for domestic uses, livestock use and water sources and points used specifically for agriculture/irrigation purposes. Examples of water points for domestic water uses included boreholes with water lifting devices, public water taps (DPs), and private water taps in a house with domestic water service. Water points and sources for livestock included cattle troughs, and chaco-dams (malambo) exclusive for animal drinking. Mapping was also done on points with multipurpose water uses such as rivers where livestock were sent to drink water at a specific location. Specific water sources for agriculture were such as micro-dams (ndiva/nduwa). Water reservoir (Nduwa) in Sango village in Moshi District council was an example of project pilot village with multipurpose water uses.

\section{Results and Discussion}

\subsection{Outcome of Tool Testing}

\subsubsection{Land Degradation Assessment}

The land degradation tool has provided a guideline on how to identify whether or not land degradation has occurred and at what extent. It focused on three indicators namely soil erosion, vegetative cover and change in greenish colour of crops/plants. Regarding soil erosion indicator, this decision making tool has covered three types of soil erosion namely sheet erosion, rill erosion and gully erosion. For all the three indicators, four levels for measuring the extent or degree of land degradation were used namely "no degradation", "low degradation", "medium degradation" and "high degradation". The no degradation level was represented by the numeral value " 0 ", low degradation level was operationalized by the scale of 1-3, medium degradation, 4-6, and high degradation, 7-9. All the three indicators were operationalized into the four levels and thereafter for every row of an indicator space was provided for farmer's scoring at the extreme right side. Results showed that, there was more degradation in lowlands (Mabilioni and Mnazi Villages) in terms of both soil and wind erosion as compared to mid and uplands.

Having identified the extent of degradation, the tool gave an opportunity for the community to recommend strategies to be undertaken under different statuses of land degradation based on the visual evidences observed by farmers from selected indicators of soil erosion, vegetative cover and crop/plant color (Table 1). Hence the tool enabled farmers and other resource users and local managers to understand land degradation status by observing visual evidences, and their severity scales and therefore to facilitate the farmer to make appropriate decision. The farmers were also provided with opportunity of judging from multiple indicators (soil erosion, vegetative cover, and crop colour) thereby triangulating evidence of land degradation, and therefore enhancing the validity of observation (Table 1 ). 
Table 1. Suggested land degradation remedial actions.

\begin{tabular}{|c|c|}
\hline $\begin{array}{l}\text { Type of land } \\
\text { degradation }\end{array}$ & Remedial actions \\
\hline Sheet erosion & $\begin{array}{l}\text { 1) Construct soil erosion control structures such as ridges, fanyajuu and terraces on steep slopes. } \\
\text { 2) Apply manure/use leguminous plants in the field to replenish the lost nutrients. } \\
\text { 3) Plant trees/leguminous trees/agroforestry trees to serve as windbreak in the field especially for the affected area. }\end{array}$ \\
\hline Rill erosion & $\begin{array}{l}\text { 1) Plant grass or encourage restoration of natural vegetation by abandoning human activities on the area. } \\
\text { 2) Use contour ridges to harvest and prevent violent flow of water during rains. }\end{array}$ \\
\hline Gully erosion & $\begin{array}{l}\text { 1) Construct gabions. } \\
\text { 2) Planting tress e.g. castrol oil trees (Minyonyo) and sisal to help hold the soil. } \\
\text { 3) Stop anthropogenic use of land surrounding the gullies to encourage natural vegetation restoration. }\end{array}$ \\
\hline $\begin{array}{l}\text { Reduction of } \\
\text { vegetation cover }\end{array}$ & $\begin{array}{l}\text { 1) Plant trees/leguminous trees/agroforestry trees in the affected area. } \\
\text { 2) Use of bench terraces. } \\
\text { 3) Use of water diversion structures. }\end{array}$ \\
\hline $\begin{array}{l}\text { Loss of } \\
\text { greenish colour }\end{array}$ & $\begin{array}{l}\text { 1) Construct water harvesting structures such as ridges, fanyajuu and terraces on steep slopes. } \\
\text { 2) Plant trees and use leguminous plants/crops around contours on steep slopes to replenish the lost nutrients. } \\
\text { 3) Use of fertilizers such as manure and inorganic fertilizers to replenish the lost nutrients. }\end{array}$ \\
\hline
\end{tabular}

\subsubsection{Soil Health Assessment}

The soil health assessment was performed with the help of soil health score sheet in farmlands. Key soil health aspects that farmers learned and practiced include ease of penetration using penetrometer, ease of infiltration, diversity of macro-life, presence of earthworms, soil structure, root development, aggregate stability of the soil samples at the 10 - $20 \mathrm{~cm}$ depth, and plant size and leaf color (Table 2 and Table 3). After the testing, farmers were able to describe types of nutrient deficiencies in their farmlands and appropriate agronomic and soil fertility measures needed to restore the soil health. The villagers were able to replicate on their own the procedures for evaluating soil health using the soil health score sheet.

A few challenges were encountered while testing with the soil health score sheet. The test needed to be conducted in cropped fields to give a real picture of the farmland soil health status. However, in fields with seasonal crops when crop residues are removed the score sheet may indicate poor vegetation cover, implying poor soil health, contrary to the real farm conditions. Amount of moisture content also need to be assessed during penetration tests because wet fields gave results that were different from very dry fields within the same area. Hence on the same field, testing during dry season would give results that are different from those taken during the rainy season. As a corrective measure, there is a need for taking into consideration season of the year, soil wetness and crop cover. In a dry soil, as happens during the dry season, this is taken care of by first pouring water into the soil and letting it infiltrate through for a day or two before test is carried out to stabilize the moisture at about field capacity.

The results of the testing in seven villages are given in Table 3.

Figure 5 shows differences in the soil health status of the different villages. Mabilioni village was lowest in ranking and Roo was highest. The health parameters that contributed most to the lower scores were, macrolife diversity, earthworms, and ground cover (Table 3). Other parameters gave somewhat average scores for many villages, with Roo village showing overall higher scores. Soil physical properties (ease of penetration, ease of infiltration, soil structure, root development and aggregate stability) were generally medium to high for most villages. Plant colour/size, as proxy for chemical soil fertility was high for Roo, Mnazi and Shigatini villages. The abnormal colours that were widely mentioned as occurring on crops, thus contributing to low soil health scores, were yellowish/pale green and purple colours, implying low levels of nitrogen and phosphorus, in the soils respectively. Generally, Mabilioni village soils were of poor health while Roo village had good health soils. All other villages had soils of medium health.

\subsubsection{Carbon Stock Assessment}

Carbon assessment is normally a technical exercise that needs to be done at required standards and accuracy. However, communities in the seven pilot villages were able to use the simplified tools prepared for assessing carbon stock (Figure 6). The tape measure that was used for measuring circumference (to be converted to diameter) was a normal standard fiber tape measure, which could easily be available in villages. Tape measures 
Table 2. The soil health assessment tool: the soil health card results score sheet.

\begin{tabular}{|c|c|c|c|c|c|}
\hline $\begin{array}{l}\text { Date } \\
\text { Agri } \\
\text { Day }\end{array}$ & $\begin{array}{l}\text { Village/Wa } \\
\text { cultural activity: } \\
\text { since } 20 \mathrm{~mm} \text { rain: }\end{array}$ & $\begin{array}{l}\text { rd/District: } \\
\text { Soil moisture condition a }\end{array}$ & $\begin{array}{l}\text { pe/Description: } \\
\text { t testing time (tick): dry . }\end{array}$ & $\begin{array}{r}\text { (draw a sketch map of te } \\
\text { Productivity } \\
\ldots \ldots \ldots \ldots \ldots \text { moist .......... }\end{array}$ & $\begin{array}{l}\text { sted area overleaf) } \\
: \ldots, \text { water logged } \ldots \ldots \ldots \ldots . . .\end{array}$ \\
\hline $\mathrm{S} / \mathrm{N}$ & Test/score & Poor (1-3) & Fair (4-6) & Good (7-9) & $\begin{array}{l}\text { Scores of individual tests runs } \\
\text { from same soil type (1-9) }\end{array}$ \\
\hline 1 & $\begin{array}{l}\text { Ease of penetration } \\
\text { (using a penetrometer) }\end{array}$ & $\begin{array}{l}\text { Wire probe will not } \\
\text { penetrate }\end{array}$ & $\begin{array}{l}\text { Wire probe penetrates } \\
\text { with difficulty to less } \\
\text { than } 20 \mathrm{~cm}\end{array}$ & $\begin{array}{l}\text { Wire probe easily } \\
\text { penetrates to } 20 \mathrm{~cm}\end{array}$ & \\
\hline 2 & Ease of infiltration & More than 7 minutes & 3 to 7 minutes & Less than 3 minutes & \\
\hline 3 & $\begin{array}{l}\text { Diversity of } \\
\text { macro-life }\end{array}$ & $\begin{array}{l}\text { Fewer than two types } \\
\text { of soil animals }\end{array}$ & $\begin{array}{l}\text { Two to five types } \\
\text { of soil animals }\end{array}$ & $\begin{array}{l}\text { More than five types } \\
\text { of soil animals }\end{array}$ & \\
\hline 4 & Earthworms & $0-3$ & $4-6$ & More than 6 & \\
\hline 5 & Soil structure & $\begin{array}{l}\text { Mostly in clods or } \\
\text { with a surface crust, } \\
\text { few crumbs }\end{array}$ & $\begin{array}{l}\text { Some clods but also } \\
\text { many } 10 \mathrm{~mm} \text { crumbs }\end{array}$ & $\begin{array}{l}\text { Friable, readily breaks } \\
\text { into } 10 \mathrm{~mm} \text { crumbs }\end{array}$ & \\
\hline 6 & Root development & $\begin{array}{l}\text { Few fine roots only } \\
\text { found near the surface }\end{array}$ & $\begin{array}{l}\text { Some fine roots mostly } \\
\text { near the surface }\end{array}$ & $\begin{array}{l}\text { Many fine roots } \\
\text { throughout }\end{array}$ & \\
\hline 7 & $\begin{array}{l}\text { Aggregate stability, } \\
10-20 \mathrm{~cm} \text { depth }\end{array}$ & $\begin{array}{l}\text { Aggregate broke apart in } \\
\text { less than one minute }\end{array}$ & $\begin{array}{l}\text { Aggregate remained } \\
\text { intact after one minute }\end{array}$ & $\begin{array}{l}\text { Aggregate remained } \\
\text { intact after swirling }\end{array}$ & \\
\hline 8 & $\begin{array}{l}\text { Soil pH, } \\
5-20 \mathrm{~cm} \text { depth }\end{array}$ & pH 5 or lower & pH 5.5 & pH 6 to $\mathrm{pH} 7$ & \\
\hline 9 & $\begin{array}{l}\text { Plant size and } \\
\text { leaf colour }\end{array}$ & $\begin{array}{l}\text { Stunted plants, leaf } \\
\text { discolouration }\end{array}$ & $\begin{array}{l}\text { Some variation in } \\
\text { growth and colour }\end{array}$ & $\begin{array}{l}\text { Appropriate leaf colour } \\
\text { and uniform plant growth }\end{array}$ & \\
\hline
\end{tabular}

Table 3. Possible causes of low test scores on soil health.

\begin{tabular}{|c|c|c|c|}
\hline $\mathbf{S} / \mathbf{N}$ & Test result & Situation indicated & Possible causes \\
\hline 1 & Low ground cover & $\begin{array}{l}\text { Ground plants absent or } \\
\text { plant growth is poor }\end{array}$ & $\begin{array}{l}\text { Unsuitable plant type(s), soil compaction, soil erosion, shading, } \\
\text { overstocking (animals eating most of the plant residues) }\end{array}$ \\
\hline 2 & $\begin{array}{l}\text { Low variety of } \\
\text { soil fauna }\end{array}$ & $\begin{array}{l}\text { Lack of food for fauna, } \\
\text { poor soil structure, presence } \\
\text { of harmful (agro)chemicals }\end{array}$ & $\begin{array}{l}\text { Sparse litter, low soil organic matter, lack of soil spaces and channels, } \\
\text { frequency or intensity of tillage has been excessive, mortality from } \\
\text { recent use of insecticides or regular use of cumulative chemical(s) such } \\
\text { as copper fungicides }\end{array}$ \\
\hline 3 & $\begin{array}{l}\text { Low earthworm } \\
\text { count }\end{array}$ & $\begin{array}{l}\text { pH unfavorable, poor food } \\
\text { supply, lack of soil spaces, } \\
\text { predators or parasites } \\
\text { present, presence of } \\
\text { harmful chemical }\end{array}$ & $\begin{array}{l}\text { Soil pH naturally low, sparse litter and/or ground cover (and roots), low } \\
\text { organic matter content, loss of topsoil, soil compaction, poor structure, } \\
\text { predators (such as flatworms) and parasites (e.g. parasitic flies, } \\
\text { mortality from recent use of insecticides or regular use of cumulative } \\
\text { chemical(s) such as copper fungicides }\end{array}$ \\
\hline 4 & $\begin{array}{c}\text { Low probe } \\
\text { penetrability }\end{array}$ & $\begin{array}{l}\text { Soil is generally hard at the } \\
\text { surface only, hard layer at } \\
\text { greater depth }\end{array}$ & $\begin{array}{l}\text { Low organic matter content, compacted by traffic or livestock due to } \\
\text { overstocking) especially if soil is wet at the time, compacted by heavy } \\
\text { vehicles or "hard pan" formed by soil inverting cultivators }\end{array}$ \\
\hline 5 & $\begin{array}{l}\text { Slow water } \\
\text { infiltration }\end{array}$ & $\begin{array}{l}\text { High proportion of clay } \\
\text { particles and lack of spaces, } \\
\text { channels or burrows in soil }\end{array}$ & $\begin{array}{l}\text { Naturally high clay content of soil type, possible loss of topsoil through } \\
\text { erosion, soil compaction, poor soil structure, lack of earthworms, } \\
\text { surface crusting }\end{array}$ \\
\hline 6 & $\begin{array}{c}\text { Poor root } \\
\text { development }\end{array}$ & $\begin{array}{l}\text { Hard soil lacking spaces, } \\
\text { poor plant nutrition, root } \\
\text { disease or attack }\end{array}$ & $\begin{array}{l}\text { Loss of topsoil, poor soil structure, soil compaction, soil pH not suitable } \\
\text { for crop, lack of major or minor nutrients, presence of soil-borne plant } \\
\text { pathogens, root-feeding nematodes or root-feeding insects }\end{array}$ \\
\hline 7 & $\begin{array}{l}\text { Poor soil } \\
\text { structure }\end{array}$ & $\begin{array}{l}\text { Powdery soil, few crumbs, } \\
\text { excessive clods }\end{array}$ & $\begin{array}{l}\text { Lack of soil-binding substances and processes, low soil organic matter } \\
\text { content (sparse ground cover), few worms, topsoil loss, soil compaction, } \\
\text { "puddling” of wet soil by livestock, excessive cultivation }\end{array}$ \\
\hline 8 & $\begin{array}{l}\text { Low aggregate stability } \\
\text { (leading to high slaking } \\
\text { of soil aggregates) }\end{array}$ & $\begin{array}{l}\text { Soil particles disperse when } \\
\text { wet }\end{array}$ & $\begin{array}{l}\text { Topsoil loss }(0-10 \mathrm{~cm}) \text {, compaction, low organic matter, excess tillage } \\
\text { down to } 20 \mathrm{~cm} \text {, poor mixing of soil by soil animals, acidic soil } \\
\text { conditions }\end{array}$ \\
\hline 9 & Poor leaf color & $\begin{array}{l}\text { Unthrifty (poorly-growing) } \\
\text { plant }\end{array}$ & $\begin{array}{l}\text { Deficiency or unavailability of one or more essential nutrients (e.g. P, } \\
\mathrm{N}, \mathrm{K}, \mathrm{Ca} \text {, etc.), (can be confirmed by soil or leaf analysis), presence of } \\
\text { some plant diseases, water logging }\end{array}$ \\
\hline
\end{tabular}




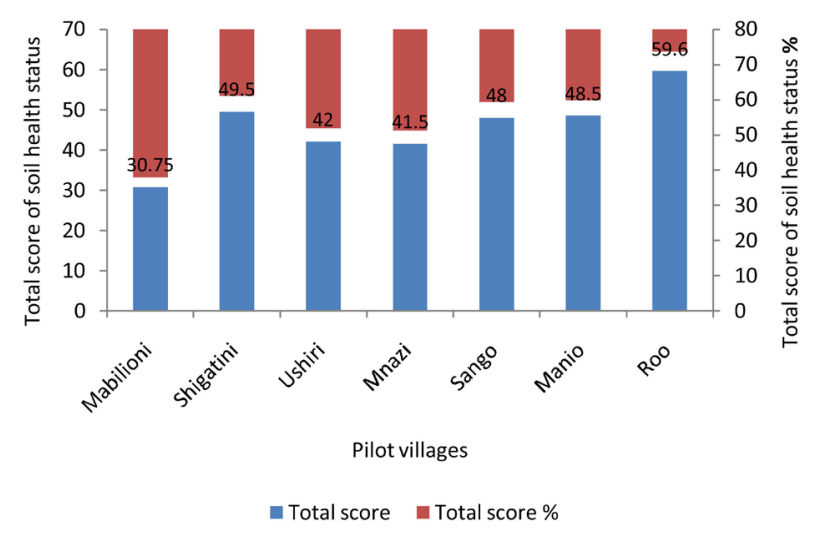

Figure 5. Soil health status in the pilot villages as captured by soil health assessment tool. Key: low $=0 \%-33 \%$; medium $=$ above $33 \%-66 \%$; high = above $66 \%-100 \%$.

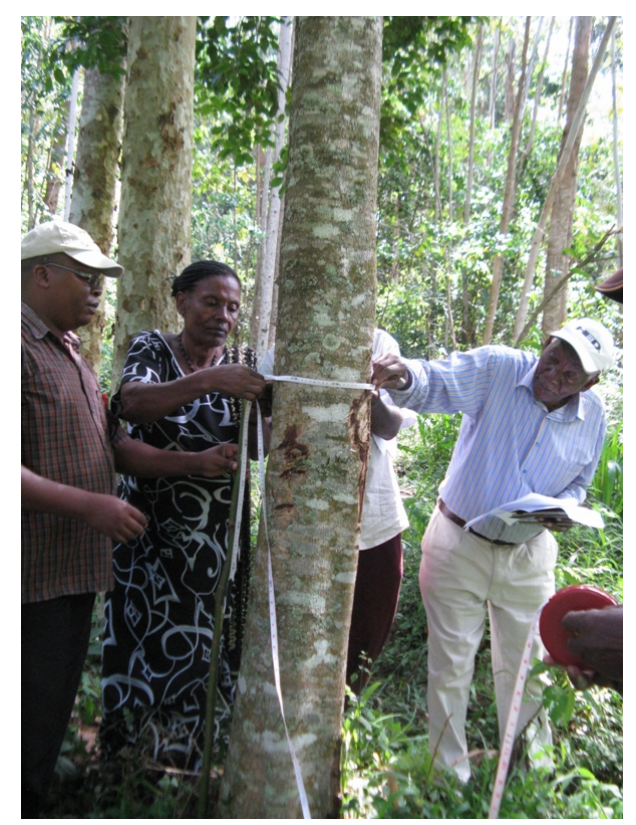

Figure 6. Participatory carbon assessment by communities in Shighatini Village, Mwanga District in Kilimanjaro Region, Tanzania.

were common to villagers doing tailoring, carpentry and masonry. Conversion of circumferences to diameters was easily done by communities using their mobile phone calculators. Complex equipment such as GPS for locating position, compass for direction and hypsometer for tree height estimation were not common to almost all villagers in all the seven villages. In this case, their use was minimized or rather used by professional foresters. That means, for carbon assessment, communities will need further detailed training or will need to be accompanied by respective district or ward forest officers.

The assessment involved hands-on exercises done by communities themselves. After explanation and demonstration on how to demarcate plots and how to take measurements, tools were given to a group of communities and they were asked to undertake the exercise by themselves. The trainers were around to assist communities where they went wrong. Some of group members were taking measurements and some recording the data. Important instrument that was fabricated locally for use was the $1.3 \mathrm{~m}$ stick, which was used to determine the height where the diameter at breast height (DBH) measurement was to be taken. The rest of the tools were the ones that could easily be bought in village shops. 
The carbon assessment toolkit was simplified in a tabular form for easy of following and recording of data. Communities had sufficient knowledge of reading, writing, and calculating basic statistics. Most of them knew basic information about trees and the role of forests for environmental benefits and livelihoods. The most interesting activity in the testing exercise for the community was the hands-on practical testing of measuring the forest condition. They actively participated to measure the diameter of trees; count and measure tree stamps and assess forest disturbance. Results revealed very few and small trees in lowlands as compared to uplands where there were good protected forests. Unmanaged forests in lowlands were diminishing and converted to bush lands probably due to double effects of climate change and overgrazing. These changes also reflected low carbon storage potential.

The main challenge in pilot villages was the fact that most villages did not have natural forests that could qualify in carbon trading. Most forest patches were small mainly of plantations, which do not qualify in the REDD+ mechanism by now.

\subsubsection{Hydrological Assessment}

The hydrological assessment involved determination and quantification of the available water resources within the village, mapping of their location, and allocating various uses to available water resources. Upland and midland villages were good in hydrological values as compared to lowlands. Using this tool, the villagers were able to quantify the amount of water (discharge in $1 / \mathrm{sec}$ ) flowing from various sources such as rivers, canals/streams, water pipe and boreholes. The villagers also were able to evaluate the physical water quality, perform reconnaissance survey of potential areas for drilling boreholes, and played a part in participatory mapping and allocation of the water resources to come up with sustainable village water resources use plans. The community appreciated the simplicity in determining the required information using the hydrological assessment tool.

Key challenges observed were availability of a flowing water source in the proximity of the training area. In some villages such as Mabilioni in Same District the trainees (and trainers) had to walk quite a distance (2 - 3 $\mathrm{km}$ ) to reach the Pangani River water source. Locating key features that signify groundwater potential was a challenge in some places, especially in villages that are located in mountain areas such as Manio Village in Siha District. Based on the hydrological analysis it was also observed that the community had a good understanding on how to preserve the water sources through planting trees around the water sources and banning the cultivation and cutting of trees along the water courses.

Key water uses emphasized were for domestic, livestock, agriculture, environment, construction and other uses. The documentation of the location and hydrological conditions of the water resources within the village were concluded by mapping of the available water resources (Figure 7) and locating areas for potential future development using the existing water resources. Existing land uses and water sources and points mapping prepared by the community is presented in Figure 7.

\section{Conclusion}

The developed decision making tools have proven to be useful tools in assisting the community and other stakeholders to plan for their present and future land uses on sustainable manner. The tested tools were on land degradation, soil health, carbon stock and hydrology. Soil health was poor in lowlands and good in midlands and uplands. Land degradation was more pronounced in lowland areas as a result of water and wind erosion of the soils. Carbon stock was assumed to be lower in lowlands because of more shrubs and less trees as compared to mid and uplands. Upland and midland villages were good in hydrological values as compared to lowlands. Generally, the tools have shown that upland village communities are better in land management than lowland communities. That means: more resources are required to be channeled to manage the more degraded lands in lowland areas of Kilimanjaro as compared to uplands. Therefore, empowering the communities with decision making tools at village level and landscape level is essential. While the region is making efforts to ensure that the land management and use is sustainable, there is a need to enforce existing laws (e.g. banning harvest of trees) and make environment a permanent agenda in local government authority meetings.

\section{Acknowledgements}

The authors appreciate the financial support from the United Nations Development Programme (UNDP), and the Regional Administrative Secretary (RAS) Kilimanjaro Region through a 4-year project on reducing land 


\section{EXISTING LAND USE IN SANGO VILLAGE}

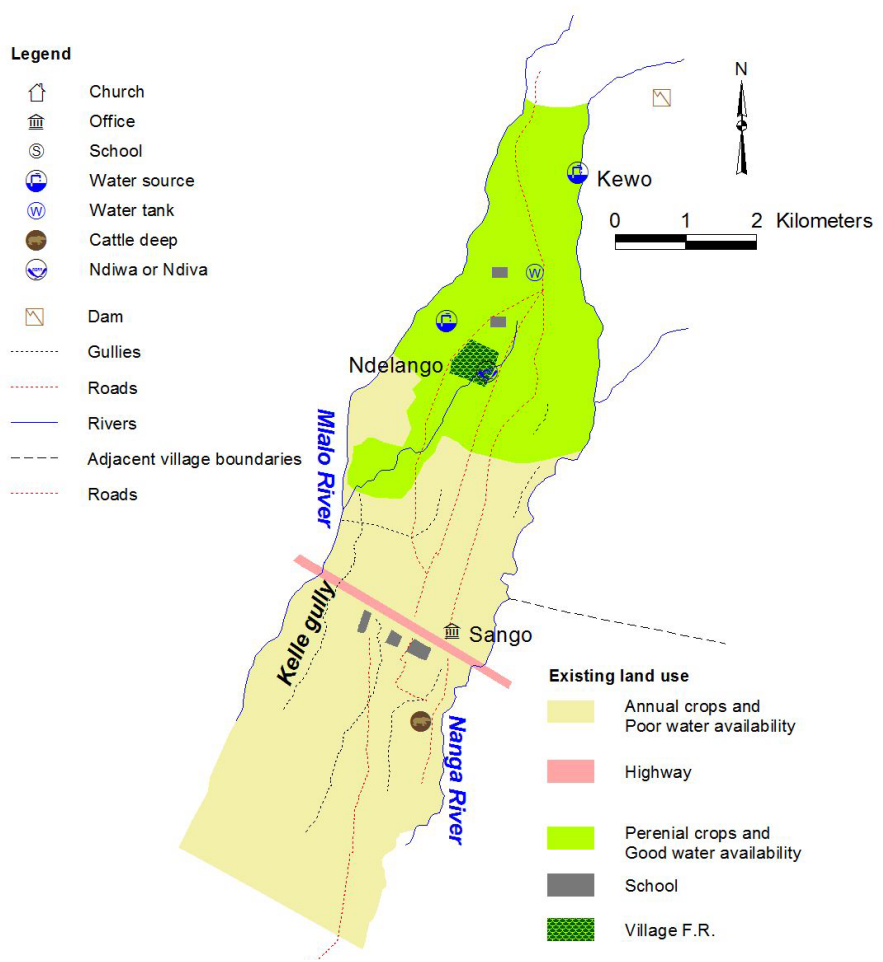

(a)

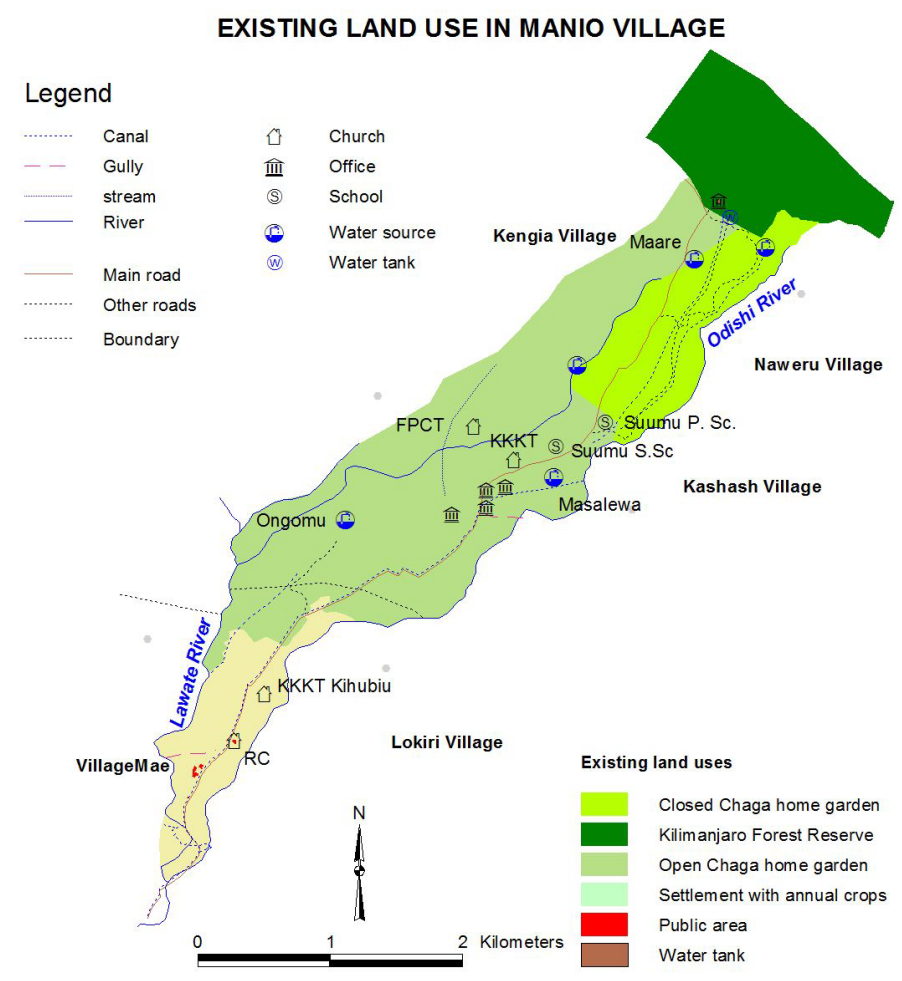

(b)

Figure 7. Participatory mapping of (a) land uses in Sango Village, Moshi rural district and (b) water resources/water points in Manio Village, Siha District, Kilimanjaro, Tanzania. 
degradation on the highlands of the Kilimanjaro Region. We are also thankful to district executive directors, district facilitation team members (DFTs), district focal persons, extension staff, pilot village leaders and all our respondents in all seven districts and villages for their cooperation during data collection exercises and validation of DMTs. Lastly, we are grateful to SLM technical team and all people who were involved in proof reading and commenting on this paper.

\section{References}

[1] FAO (2000) Land Resources: Sustainable-Land-Management/Field-Farm-Level.

[2] NLUPC (1998) Guidelines for Participatory Village Land Use Management in Tanzania. National Land Use Planning Commission, Ministry of Lands and Human Settlements Development. Dar es Salaam, Tanzania.

[3] UNDP (2010) Reducing Land Degradation on the Highlands of Kilimanjaro Region. United Nations Development Program, Tanzania LRM Project Document. http://www.tz.undp.org/content/dam/tanzania/Sustainable\%20Land\%20Management\%20in\%20Kilimanjaro.pdf

[4] URT (1998) Kilimanjaro Region Socio-Economic Profile. The Planning Commission Dar es Salaam and Regional Commissioner's office, Kilimanjaro Region.

[5] URT (2013) Population and Housing Census. Population Distribution by Administrative Areas. National Bureau of Statistics, Ministry of Finance, Dar es Salaam, and Office of Chief Government Statistician, President's Office, Finance, Economy and Development Planning, Zanzibar, 244 p.

[6] Plane, D.A. and Rogerson, P.A. (1994) The Geographical Analysis of Populations: With Applications to Planning and Business. John Wiley \& Sons, New York.

[7] Tanzania Meteorological Agency (TMA) (2005) Annual Report. Government Printer, Dar es Salaam, Tanzania.

[8] Maro, G.P., Mrema, J.P., Msanya, B.M., Janssen, B.H. and Teri, J.M. (2014) Developing a Coffee Yield Prediction and Integrated Soil Fertility Management Recommendation Model for Northern Tanzania. International Journal of Plant \& Soil Science, 3, 380-396. http://dx.doi.org/10.9734/IJPSS/2014/6883

[9] Stocking and Murnaghan (2001) Handbook for Field Assessment of Land Degradation. Earthscan, London.

[10] UNFCC (2013) Estimation of Carbon Stocks and Change in Carbon Stocks of Trees and Shrubs in A/R CDM Project Activities. http://cdm.unfccc.int/methodologies/ARmethodologies/tools/ar-am-tool-14-v4.1.pdf

[11] NAFORMA (2011) Forest Inventory Systems and the FAO/NAFORMA Program.

[12] Jenkins, A. (2006) Northern Rivers Soil Health Card: A Monitoring Tool for Farmers Developed by Farmers. NSW Department of Primary Industry, Wollongbar Agricultural Institute, Bruxner Hwy Wollongbar. www.dpi.nsw.gov.au

[13] Jenkins, A. (2010) Striking a Match: How to Ignite a Passion for Soils. World Congress of Soil Science, Soil Solutions for a Changing World. Brisbane, 26-29.

[14] Mango, G. and Kalenzi, D. (2011) The Study to Develop a Strategy for Establishing Cost Effective Land Use Plans in Iringa and Njombe Regions. URT, National Land Use Planning Commission Report, Dar es Salaam, 47 p.

[15] IIED (2010) Participatory Land Use Planning as a Tool for Community Empowerment in Northern Tanzania. Ujamaa Community Resource Team, Gatekeeper 147: December 2010. International Institute for Environment and Development. http://pubs.iied.org/pdfs/14608IIED.pdf 
Scientific Research Publishing (SCIRP) is one of the largest Open Access journal publishers. It is currently publishing more than 200 open access, online, peer-reviewed journals covering a wide range of academic disciplines. SCIRP serves the worldwide academic communities and contributes to the progress and application of science with its publication.

Other selected journals from SCIRP are listed as below. Submit your manuscript to us via either submit@scirp.org or Online Submission Portal.
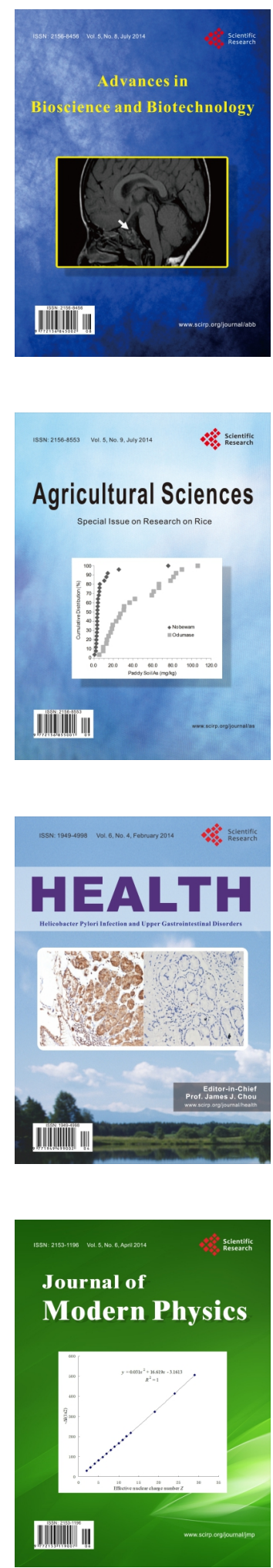
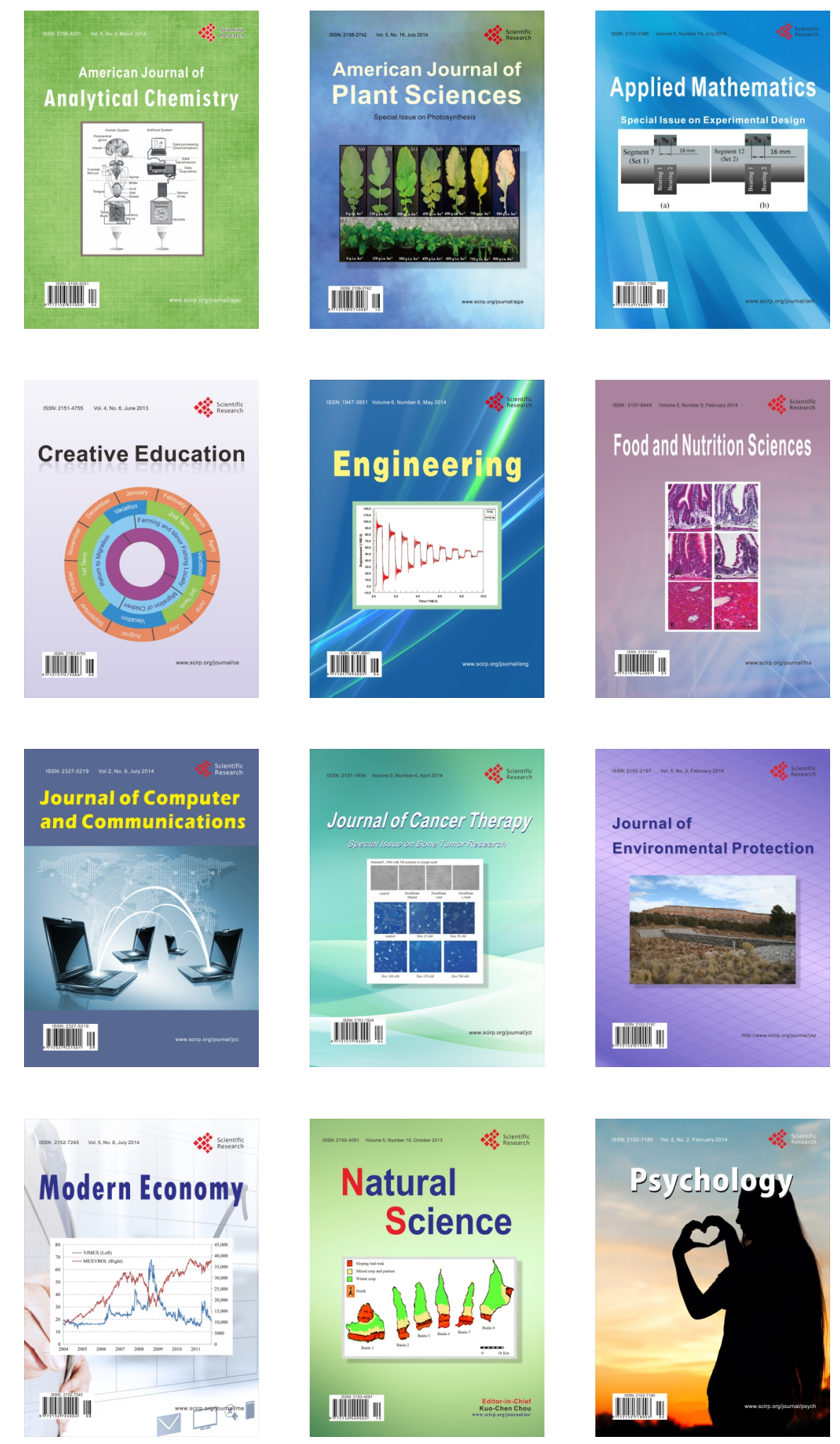